\title{
Pengaruh Pemberian Vitamin E Terhadap Kadar MDA Plasma Darah Pasca Latihan Fisik Submaksimal
}

\author{
Mulyono, Wahyu Susiloningsih \\ Universitas PGRI Adi Buana Surabaya \\ e-mail:mee4hme@yahoo.com
}

\begin{abstract}
ABSRACT
In physical activity, in addition to forming free radical compounds, the body will form antibodies in the form of endogenous antioxidants. In the event of an imbalance in the formation of free radicals with antioxidants (oxidative stress) exogenous antioxidant administration will help to restore the balance of free radicals with - antioxidants. Provision of vitamins and massage manipulation immediately after physical exercise is expected to help in decreasing levels of MDA Plasma as one indicator of the degree of free radical in the blood and helps speed up the recovery of the body.

It is an experimental research with post-test control group design with sample of 20 college students of Unipa Surabaya. Which is divided into 2 groups with each group amounted to 10 college students. The group is Control group and Vitamin E group. The all group performed $2.4 \mathrm{~km}$ run, the treatment was given after the sample did the physical activity. After 1 hour of treatment each group was taken by radially to see blood MDA plasma levels.

After processed data got average of plasma MDA level of each group that is control group with mean $8,0870 \mathrm{nmol} / \mathrm{ml}$, vitamin E group with average 2,9020 nmol/ml. From the statistical $t$ test obtained of $P$ value $<0.05$. Thus, there was significant difference of MDA Plasma level between control group and vitamin E after physical exercise.
\end{abstract}

Keywords: Physical activity, MDA Plasma, Antioxidant, and Vitamin E.

\begin{abstract}
ABSTRAK
Dalam aktivitas fisik, selain membentuk senyawa radikal bebas, tubuh akan membentuk antibodi dalam bentuk antioksidan endogen. Jika terjadi ketidakseimbangan dalam pembentukan radikal bebas dengan antioksidan (oksidatif stres) maka pemberian antioksidan eksogen akan membantu mengembalikan keseimbangan radikal bebas dengan antioksidan. Penyediaan vitamin dan manipulasi pijat segera setelah latihan fisik diharapkan bisa membantu dalam menurunkan kadar MDA Plasma sebagai salah satu indikator tingkat radikal bebas dalam darah dan membantu mempercepat pemulihan tubuh.

Penelitian ini merupakan penelitian eksperimental dengan desain kelompok kontrol post-test dengan sampel 20 mahasiswa Unipa Surabaya. Yang terbagi menjadi 2 kelompok dengan masing-masing kelompok berjumlah 10 mahasiswa. Kelompok ini adalah Kelompok kontrol dan kelompok Vitamin E. Semua kelompok melakukan lari 2,4 km, perlakuan diberikan setelah sampel melakukan aktivitas fisik. Setelah 1 jam pengobatan, masing-masing kelompok diambil secara radial untuk melihat tingkat plasma darah MDA.

Setelah data yang diolah didapatkan rata-rata kadar MDA plasma masing-masing kelompok yaitu kelompok kontrol dengan rata-rata 8,0870 nmol/ml, kelompok vitamin $\mathrm{E}$ dengan rata-rata $2.9020 \mathrm{nmol} / \mathrm{ml}$. Dari uji statistik diperoleh nilai $\mathrm{P}<0,05$. Dengan demikian ada perbedaan tingkat MDA Plasma yang signifikan antara kelompok kontrol dan vitamin E setelah latihan fisik.
\end{abstract}


Penelitian ini menunjukan bahwa dengan pemberian vitamin E setelah latihan fisik dapat membantu menurunkan kadar MDA Plasma yang merupakan indicator tingkat radikal bebas.

Kata kunci: Aktivitas fisik, MDA Plasma, Antioksidan dan Vitamin E

\section{PENDAHULUAN}

Sewaktu aktivitas fisik yang mengedepankan peningkatan kinerja fisik untuk prestasi memiliki potensi terhadap masalah kesehatan itu sendiri, sebab aktivitas fisik tidak hanya memiliki manfaat tetapi juga memiliki resiko. Resiko terhadap kerusakan jaringan akan terjadi pada aktifitas fisik maksimal maupun submaksimal. Sebab aktivitas fisik memiliki potensi terhadap timbulnya radikal bebas dan penurunan proteksi anti radikal bebas pada tubuh (Balkhrisnan, 1998).

Beberapa peristiwa atau proses telah dihipotesiskan oleh para ahli sebagai sumber pembentukan senyawa radikal dan senyawa oksidan lainnya yaitu peningkatan konsumsi oksigen, pergeseran sirkulasi, peningkatan sekresi adrenalin dan kera-dangan (Halliwell \& Gutteridge, 1999), peningkatan suhu tubuh (Sjodin dkk., 1990; Harjanto, 2003). Paparan bahan polutan udara juga dapat meningkatkan kandungan atau pembentukan senyawa radikal dalam tubuh (Suryohudoyo, 1997; Prahalad dkk, 2001).

Adanya pembentukan radikal bebas dapat berpotensi terhadap peningkatan peroksidasi lemak, oksidasi glutathion, dan kerusakan oksidatif protein. MDA (malondialdehyde) plasma merupakan salah satu indikator yang memiliki sensitivitas reaksi paling tinggi ketika dalam suatu jaringan terdapat radikal bebas.

Vitamin E berfungsi sebagai donor ion hidrogen yang mampu mengubah radikal peroksil (hasil peroksidasi lipid) menjadi radikal tokoferol yang kurang reaktif, sehingga tidak mampu merusak rantai asam lemak. 
Dalam hal mengurangi resiko kerusakan sel dan mempercepat proses pemulihan maka diperlukan formulasi asupan vitamin yang tepat dan waktu pemberian yang sesuai serta pulih asal sirkulasi darah dengan cepat. Pemberian vitamin E setelah latihan fisik diharapkan mampu menetralisir radikal bebas dengan waktu yang singkat.

Pentingnya proses pemulihan fungsi biologis dengan menghambat atau menetralisir pembentukan radikal bebas setelah latihan fisik yang mempengaruhi kondisi fisik, kinerja maupun derajat kesehatan, maka perlu dilakukan pembaharuan konsep pemberian antioksidan. Untuk itu tujuan dari penelitian ini adalah untuk mengetahui pengaruh pemberian vitamin $\mathrm{E}$ terhadap kadar MDA plasma setelah aktivitas fisik submaksimal.

\section{METODE PENELITIAN}

Jenis penelitian yang akan dilakukan adalah penelitian eksperimental laboratoris. Rancangan penelitian ini adalah The Randomized Post Test Only Control Grup Design.

\section{Populasi}

Populasi dalam penelitian ini adalah Mahasiswa Jurusan Pendidikan Olahraga Universitas PGRI Adibuana Surabaya.

\section{Sampel}

Jumlah sampel yang digunakan dalam penelitian ini masing-masing kelompok $\mathrm{n}=10$ sebanyak 2 (dua) kelompok. Yaitu: kelompok control dan kelompok Vitamin E.

Bahan dan Instrumen dalam Penelitian ini adalah:

1. Vitamin E tablet;

2. Darah di ambil sebanyak $3 \mathrm{cc}$;

3. Lintasan lari; dan

4. Alat suntik lengkap.

Dilakukan uji normalitas setelah itu data yang terkumpul dari pengukuran dianalisa melalui bantuan computer program SPSS for windows dengan taraf signifikan 95\%. Uji statistik yang digunakan adalah uji-t. 
Tabel 1. Statistik deskriptif masing kelompok menurut Kadar MDA Plasma Darah dalam satuan $\mathrm{mmol} / \mathrm{ml}$

\begin{tabular}{|l|c|c|c|c|c|}
\hline Kelompok & $\mathrm{N}$ & Min & Max & mean & SD \\
\hline Kontrol & 10 & 7,07 & 8,86 & 8,0870 & 0,47420 \\
\hline Vitamin E & 10 & 2,30 & 3,40 & 2,9020 & 0,36264 \\
\hline
\end{tabular}

\section{HASIL DAN PEMBAHASAN}

Hasil yang diperoleh setelah melakukan pengumpulan data didapat berupa tabel hasil rerata MDA Plasma masingmasing kelompok (lihat tabel 1).

Dari data pada tabel 1 kemudian dilakukan uji-t untuk mengetahui perbedaan rerata pada kelompok kontrol dan perlakuan. Hasil dari uji-t dapat dilihat pada tabel 2.

\section{Interpretasi}

Dari hasil analisa data tersebut didapat bahwa secara bermakna berdasar analisis anova terdapat perbedaan yang bermakna dari kadar MDA Plasma masing masing kelompok. Hal ini karena nilai $\mathrm{P}<$ 0.05. Dari data tersebut di dapat rata-rata MDA Plasma kelompok control sebesar 8, 087 dengan satandar deviasi 0,474 . Pada kelompok vitamin E terdapat rerata MDA Plasma sebesar 2, 902 dengan standar deviasi 0,362 . Dari data uji t test terdapat nilai $\mathrm{P}$ value sebesar $\mathrm{P}<005$ yang dapat diartikan bahwa terdapat perbedaan secara bermakna antara kelompok kontrol dengan kelompok vitamin E.

Tabel 2. Distribusi rata-rata Kadar MDA Plasma setelah perlakuan.

One-Sample Test

\begin{tabular}{|c|c|c|c|c|c|c|}
\hline & \multicolumn{6}{|c|}{ Test Value $=0.05$} \\
\hline & \multirow[t]{2}{*}{$\mathrm{t}$} & \multirow[t]{2}{*}{$d f$} & \multirow[t]{2}{*}{$\begin{array}{l}\text { Sig. (2- } \\
\text { tailed) }\end{array}$} & \multirow[t]{2}{*}{$\begin{array}{c}\text { Mean } \\
\text { Difference }\end{array}$} & \multicolumn{2}{|c|}{$\begin{array}{l}95 \% \text { Confidence } \\
\text { Interval of the } \\
\text { Difference }\end{array}$} \\
\hline & & & & & Lower & Upper \\
\hline Vitamin E & 24.870 & 9 & .000 & 2.85200 & 2.5926 & 3.1114 \\
\hline Kontrol & 53.596 & 9 & .000 & 8.03700 & 7.6978 & 8.3762 \\
\hline
\end{tabular}




\section{Pembahasan}

Dari masing kelompok didapat nilai $\mathrm{P}$ value $<0.05$ yang berarti terdapat perbedaan antara masing-masing kelompok terhadap kadar MDA Plasma setelah pemberian vitamin E. Radikal bebas dapat terbentuk selama dan setelah latihan oleh otot yang berkontraksi serta jaringan yang mengalami iskemikreperfusi (Chevion et al., 2003). Pembentukan radikal bebas teru-tama dihasilkan oleh otot rangka yang berkontraksi (Jackson, 2005). Saat kerja maksimal dan lama maka konsumsi oksigen dalam tubuh meningkat sampai beberapa kali dibanding konsumsi waktu istirahat (Clanton, 1999). Meningkatnya konsumsi oksigen dapat meningkatkan pembentukan senyawa oksidan melalui berbagai proses.

Aktivitas fisik yang dikemas dalam kegiatan olahraga pada dasarnya adalah stresor yang diharapkan menjadi stimulator sehingga menghasilkan adaptasi tubuh. Tetapi aktivitas fisik yang selalu mene-kankan peningkatan kinerja fisik dapat menimbulkan gangguan homeostatis pada tubuh, yang dapat menyebabkan pening-katan kerusakan jaringan yaitu kerusakan membran sel yang diakibatkan oleh senya-wa toksik seperti $M D A$ (malondialdehyde). Kerusakan jaringan terutama oleh radikal bebas oksigen yang ditimbulkan oleh akti-vitas fisik (Balakhrisnan, 1998; Ji, 1999; Halliwel, 1999). Aktivitas fisik dapat meningkatkan pembentukan radikal bebas melalui; peningkatan reduksi $\mathrm{O} 2$ dalam mitokhondria, peningkatan metabolisme epinefrin dan katekolamin, peningkatan aktivitas leukosit dan makrofag pada daerah kerusakan, peningkatan xanthine oxidase, serta peningkatan aktivitas $\mathrm{NADPH} \quad$ (nicotinamide adenine dinucleotide phosphate) oxidase dan cytochrome P.450. Pembentukan radikal bebas mulai meningkat $12-24$ jam setelah aktivitas fisik, mencapai puncaknya setelah 48-72 jam dan kembali normal 168 
jam setelah aktivitas fisik (Len $\mathbf{J}$ dkk, 2002).

Radikal bebas adalah atom atau molekul yang mempunyai elektron yang tidak berpasangan pada orbital terluarnya dan dapat berdiri sendiri (Clarkson and Thompson, 2000; Slater, 1984). Kebanyak-an radikal bebas bereaksi secara cepat dengan atom lain untuk mengisi orbital yang tidak berpasangan, sehingga radikal bebas normalnya berdiri sendiri hanya dalam periode waktu yang singkat sebelum menyatu dengan atom lain. Simbol untuk radikal bebas adalah sebuah titik (R·), yang berada di dekat simbol atom. Radikal bebas mempunyai peran dalam fungsi normal dan abnormal tubuh. Radikal bebas yang penting secara biologis antara lain anion superoksida $\left(\mathrm{O}^{2} \cdot-\right)$, radikal hidroksil $(\mathrm{OH} \cdot)$, dan nitric oxide (NO·) (Vander et al., 2001). Bentuk radikal bebas yang lain adalah hydroperoxyl $\left(\mathrm{HO}^{2} \cdot\right)$, peroxyl $\left(\mathrm{RO}^{2} \cdot\right)$, alkoxyl (RO·), carbonate $\left(\mathrm{CO}^{3} \cdot-\right)$, carbon dioxide $\left(\mathrm{CO}^{2} \cdot-\right)$, atomic chlorine $(\mathrm{Cl} \cdot)$, nitrogen dioxide $\left(\mathrm{NO}^{2}\right.$.) (Halliwell and Whiteman, 2004). Radikal bebas bisa bermuatan negatif, bermuatan positif, dan juga bermuatan netral (Slater, 1984; Vander et al., 2001).

Tubuh mempunyai sistem pertahanan terhadap radikal bebas agar radikal bebas tidak menyebabkan efek yang merusak. Sistem pertahan ini antara lain enzim superoxide dismutase yang terdapat di mitokondria dan sitosol, enzim catalase, dan enzim glutahtion peroxidase (Jackson, 2005; Singh, 1992). Sebagai tambahan bagi sistem pertahanan yang berbentuk enzim, sel juga dapat meningkatkan produksi stress proteins atau disebut juga heat shock proteins (HSPs) untuk melindungi sel dari stres oksidatif dan bentuk stres yang lain (Khassaf et al., 2003).

Vitamin E penting untuk melindungi membran sel darah merah yang kaya akan asam lemak tidak jenuh ganda dari kerusakan akibat oksidasi. Selain itu vitamin $\mathrm{E}$ melindungi lipoprotein dalam 
sirkulasi LDL teroksidasi yang ternyata memegang peranan penting dalam menyebabkan aterosklerosis. Vitamin $\mathrm{E}$ dosis besar (1600 mg/hari) melindungi LDL dari oksidasi. Meskipun masih kontradiktif, beberapa hasil penelitian epidemiologik mengatakan bahwa vitamin E dapat memproteksi penyakit kardiovaskuler, namun mekanisme kerjanya tidak jelas. Vitamin E mengatur proliferasi sel otot polos pembuluh darah, menyebabkan vasodilatasi dan menghambat baik aktivasi trombosit maupun adhesi lekosit. Vitamin E juga melindungi $\beta$-karoten dari oksidasi (Dewoto, H.R., 2007).

Vitamin E merupakan antioksidan (pencegah oksidasi) biologis yang berdiri sebagai benteng pertahanan pertama melawan peroksida lipid yang menghasilkan radikal bebas penyebab kerusakan jaringan. Senyawa yang secara kimia juga disebut tokoferol ini mempunyai kemampuan "melumpuhkan" radikal bebas (molekul reaktif, pemicu oksidasi) dan melindungi membran sel dari serangan radikal bebas. Vitamin E merupakan antioksidan dan berfungsi penting dalam pemeliharaan integritas membrane sel utama tubuh (Allen, et all, 2001). Vitamin E mengendalikan peroksida lemak dengan menyumbangkan hidrogen ke dalam reaksi yang mampu mengubah radikal peroksil (hasil peroksida lipid) menjadi radikal tokoferol yang kurang reaktif, sehingga tidak mampu merusak rantai asam lemak dan selanjutnya melindungi sel dari kerusakan (Winarsi, 2007; Hariatmi, 2004).

\section{KESIMPULAN}

Dari hari analisis data didapat bahwa adanya pemberian vitamin E segera setelah latihan fisik submaksimal secara signifikan memberikan penurunan kadar MDA plasma darah yang merupakan salah satu indikator radikal bebas dalam darah. Bahwa dalam rangka mempercepat pemulihan setelah latihan fisik yang melelahkan dalam pemberian asupan antioksidan perlu memperhatikan jangka waktu pemberian antioksidan, hal ini dikarenakan radikal 
bebas akan meningkat 12-24 jam setelah

aktifitas fisik yang melelahkan.

\section{DAFTAR PUSTAKA}

Adam, G.M. (2002). Exercise physiology, laboratory manual. New York: Mcgraw-Hill Companis MC.

Allen R.G., Tressini M. (2000). Oxidative stress and gene regulation. Free Radical Biol Med. 28:463-99.

Astrand, P.O., and Rodahl, K. (1970). Text Book of Work Physiology. 3th ed. New York: Mc. Graw Hill Book Company.

Barja, G.C. (1994). Free Radical and Respiration. New York: Oxford University Press.

Bompa, Tudor O. (1994). Theory and methodology of training: the key to athelic performance. IOWA: Kendall/Hunt Publishing Company.

Casaburi, R. (1992). Principles of Exercise Training. American College of Chest Physicians, 101, 263-267.

Chevion, et all. (2003). Plasma antioxidant status and cell injury after severe physical exercise. PNAS vol 100. No. 9. 2003.

Clanton, et al. (1999). NMR spin trapping: Detection of free radical reactions using a phosphorus-containing nitrone spin trap. International Society for Magnetic Resonance in Medicine. Volume 42, Issue 2 Pages 215-415.
Cooper, K.H. (2000). Antioxidant Revolution. Tennessee: Thomas Nelson Publishers.

Devlin, M.T. (2002). Bioenergetics and oxidative metabolism in: biochemistry with clinical correlations. 5th ed. Wiley-liss, Canada. 590-592.

Dewoto, H.R. (2007). Pengembangan Obat Tradisional Indonesia menjadi Fitofa. Majalah Kedokteran Indonesia.

Droge W. (2002). Free radicals in the physiological control of cell function. Physiol Rev. 82:47-95.

Evans, W. J. (2000). Vitamin E, vitamin $C$, and exercise. Am J ClinNutr, 72, $647 \mathrm{~S}-52 \mathrm{~S}$.

Foss L.M. (1998). Physiology basis for exercise and sport. New York: McGraw Hill Book Company.

Halliwell B. (1999). Free radicals in biology and medicine. Oxford, New York, Toronto. P.10.

Ksing. (2000). Physiology of immune system and exercise. Sports Medicine and Physiology 98-100.

Khassaf M., et al. (2003). Effect of vitamin $C$ supplements on antioxidant defense and stress proteins in human lymphocytes and skeletal muscle. J Physiol. 549:645-652.

Kusumawati, Diah. (2004). Bersahabat dengan hewan coba. Yogyakarta: Gajah Mada University Press.

Sjodin, Bertil., Westing, Hellsten, Ylva, and Apple, Fred S. (1990). Biochemical mechanisms for oxygen free radical formation during exercise. Sports Medicine, 10(4): 236-254. 
Slater, T. F. (1984). Free-radical mechanisms in tissue injury. Biochem J, 222, 1-15.

Tambunan, S.D. (2004). Pemberian suplemen vitamin $C$ dan vitamin $E$ pada olahraga. Majalah Gizmindo.

Winarsi, Hery. (2007). Antioksidan alami dan radikal bebas. Yogyakarta: Kanisius.
Wirakusumah, E. S. (2000). Tetap bugar di usia lanjut. Jakarta: Trubus Agriwidya. Hal. 6-97.

Wuryastuti, H. (2000). Stress oksidatif dan implikasinya terhadap kesehatan, (Pidato) Pengukuhan Guru Besar Fakultas Kedokteran Hewan, UGM, 39 halaman. 